Arts for which teaching was provided, and Bedford College became one of the most important as well as the largest of the colleges for women in the univer. sities of Great Britain.

Dame Margaret's services to the University of London were notable. It was only four years after her appointment to Bedford College that she was elected to represent the Faculty of Arts on the University Senate, and she was repeatedly re-elected in this capacity until her retirement in 1929. It was very unusual for the head of a college to be elected by the professors, readers and teachers of a faculty as one of their Senate representatives; but the Faculty of Arts had been quick to recognize the administrative ability of the new principal of Bedford, and to see that she would be a tactful advocate of their views. She was an active member of the Academic Council from 1911 until 1929, and also served on a score or more of Senate committees dealing with a wide range of matters, scholastic and social. Of some of these she served as chairman, notably of the University Scholarships Committee, to the work of which she devoted much time when the annual awards were under consideration. Her views on university matters commanded attention and respect. She was responsive to new ideas and encouraging to the younger generation and to colleagues who desired to see improvements made in courses of study or examinations. For her services to education she was created D.B.E. in 1932. The honorary degree of D.Litt. was conferred upon her by the University of Reading in 1937. She was a fellow of Newnham College, Cambridge, from 1905 until 1936.

Dame Margaret was unassuming in manner and blessed with a quiet charm and a ready smilesometimes said to be a disarming asset. There are gifts of courtesy and kindness which are always recognized and are particularly valuable in one holding an administrative appointment, for they serve to soften the unavoidable asperities which such an office may involve. Dame Margaret Tuke possessed these gifts in a very special degree, and leaves behind her a memory which is sweet and fragranta memory which those who were privileged to know her will always treasure. Frank Horton

\section{Prof. P. M. Roxby}

Prof. Percy Maude Roxby, as his second name and surname imply, belonged by descent to families long known for service to our public life, especially in the Church. He was the youngest son of the Rev. H. M. Roxby, vicar of Buckden, Hunts, and it is highly characteristic that he had taken a house at Buckden with a view to retirement there, so deep were his attachments to the rural tradition of England, in spite of all the devotion he had lavished upon the University of Liverpool and its students over a period of forty years.

Born on November 21, 1880, Roxby was educated at Bromsgrove School and Christ Church, Oxford, to which he went with an open scholarship in history. Hefollowed this up by gaining the Gladstone Memorial Prize in 1902 and a first-class in modern history in 1903. After graduation, he studied under Prof. A. J. Herbertson, then recently settled in Oxford as head of the Geography Department. Before he had completed his projected scheme, the University of Liverpool inquired for someone to teach geography, and Herbertson sent Roxby to begin what was to be a great life-work as a teacher. After various preliminary stages he was given a full lectureship with the responsibility for geography in the University of Liverpool in 1908. He was awarded the Albert Kahn Travelling Fellowship in 1912 and visited the United States, India and China, beginning in connexion with the last-named what became a life-long attachment and devotion. In 1917 a new chair of geography was given to Liverpool in recognition of Roxby's work, and he held the professorship until 1944.

Roxby's welcome to foreign students in his department brought him notable recruits, including some like Prof. Chang from China and Profs. Amer, Awad, Huzayyin and others from Egypt. He was given leave to act as a member of the China Education Commission in 1921 and, with this added experience of the East, he wrote valuable articles to help teachers and students to understand and interpret China. In 1930 he was invited to act for a year as visiting professor in the Egyptian University at Cairo, where some of his students were implanting his tradition. In the same year he became president of the Geo. graphical Section of the British Association for the Advancement of Science, and his address was a notable plea for the humanist approach to geography.

Uxtder such a vital teacher, the friend of all his students, the Geography Department at Liverpool grew and became one of the acknowledged sources of strength of the University. In addition to lectures, discussions, and help with essays and theses, Roxby gave his time without stint to his students and their problems, personal as well as scientific. He also spent perhaps too much of his time and strength on geographical, educational and international study groups up and down the country without thought of fee or reward. His position as an acknowledged leader of efforts for international understanding became clear as the years passed, and he devoted much thought to committees promoting cultural relations with China and Chinese universities. This ceaseless activity perhaps lessened his output of printed work, but he contributed articles on China to the "Encyclopædia Britannica" and to various reviews, and this culminated in his editing of the Naval Intelligence Handbook on China printed for official use during the 1939-45 war period. It is greatly to be hoped that this monumental work, to which he contributed so much, may soon be made available for general use.

During the War, Roxby's school of geography was to a large extent evacuated from Liverpool to Harlech, and Roxby became for a while responsible for the part of the University of Liverpool installed in that beautiful mountain region, which made a strong appeal to him and led him to encourage students before and after graduation to concern themselves with studies of Wales. If, however, China, Egypt, Lancashire, East Anglia and Wales held his special interest, as a stream of publications by his students indicates, his sympathies were universal, and all superiority complexes were alien to his open mind, which yet maintained a strong loyalty to his own origins.

In 1944 the British Council invited Roxby to become its chief representative in China, and this led him to anticipate his retirement from the University of Liverpool, where he had for so long been an outstanding and beloved member of the professoria] staff. He had married in 1941 Miss M. P. Howden, lecturer in history in the University, and with Mrs. 
Roxby he went out to China in 1945, making plans to help Chinese colleagues in educational and other fields to rehabilitate their cultural life after the dislocation due to so many years of war. Roxby was no westernizer; he loved Chinese thought and Chinese art, and at the same time felt deeply the problem of Chinese rural poverty. One may say that he carried on at least two life-works, one for geographical thought in Great Britain, and especially at the University of Liverpool, and one for and in China. His work for Egypt was scarcely less. His students have spread far and wide, and much of his thought is included in their published work, which habitually refers to him as the source from which they have derived their inspiration. His colleagues in other universities found his selfless co-operation a great support and encouragement, and his help to the Geographical Association through many years is gratefully acknowledged.
WE regret to announce the following deaths :

Prof. V. M. Goldschmidt, For.Mem.R.S., formerly professor of geology and mineralogy in the University of Oslo, on March 20.

Sir Halford Mackinder, P.C., sometime director of the London School of Economics and formerly professor of geography in the University of London, on March 6, aged eighty-six.

Prof. B. A. MeSwiney, F.R.S., professor of physiology, Sherrington School of Physiology, St. Thomas's Hospital, London, on March 8, aged fifty-two.

Dr. Walter Ramsden, senior fellow of Pembroke College, Oxford, and emeritus professor of biochemistry in the University of Liverpool, on March 26, aged seventy-eight.

Dr. Alexander Scott, F.R.S., formerly director of scientific research at the British Museum, on March 10 , aged ninety-three.

\section{NEWS and VIEWS}

\section{Astrophysics at Cambridge: Prof. F. J. M. Stratton, O.B.E., F.R.S.}

Prof. F. J. M. Stratron retires from the chair of astrophysics at Cambridge on September 30. Thus will end an officisl connexion with the Solar Physics Observatory which dates back to 1909. In that year he was appointed assistant in astrophysics at the Newall Telescope, Cambridge Observatory, while in 1913, when the astronomical work at South Kensington was fused with that of the Newall Telescope under the name of the Solar Physics Observatory, he became assistant director to Prof. H. F. Newall. After the First World War, in which he served with distinction in the Royal Engineers, Stratton was forced by the pressure of his College duties to resign his official post at the Observatory. His research, however, was still carried on from there, and on the retirement of Newall in 1928 Stratton was appointed to the chair of astrophysics and to the directorship of the Observatory. Through his efforts, aided by those of happily chosen successive assistant directors, the Solar Physics Observatory has become to-day, it will be generally agreed, the leading centre for astrophysical research in Great Britain and the training ground for astronomers from many lands.

Prof. Stratton's own researches have covered a wide field, ranging from problems in gravitational and positional astronomy to investigations in astrophysics. He is best known, however, for his work on novæ-initiated by his brilliant discovery of $A$-type and $B$-type absorption lines simultaneously appearing in the spectrum of Nova Geminorum II, each type with its own velocity displacement, and culminating in his work on Nova Herculis 1934 and the magnificent atlas of its spectra. $\mathrm{He}$ has been an assiduous observer of solar eclipses, and the ultra-violet spectra secured by C. R. Davidson and him of the solar chromosphere at Sumatra in 1926, one of the few occasions on which he has experienced clear skies, have clarified many problems in solar physics. Those who know Prof. Stratton best expect that official retirement will be the signal for a fresh burst of activity, and they look forward to further research and to his beneficent presence at international meetings of astronomers for many years to come.

\section{Dr. R. O. Redman, F.R.S.}

DR. R. O. Kedman, chief assistant at the Radcliffe Observatory, Pretoria, has been appointed professor of astrophysics and director of the Observatories of the University of Cambridge on the retirement of Prof. F. J. M. Stratton. A Sheepshanks Exhibitioner and Isaac Newton Student at Cambridge, he spent part of his time as a student at the Dominion Astrophysical Observatory, Victoria, under Prof. J. S. Plaskett. His work there on the galactic rotation of late-type stars led to his return to Cambridge as assistant director of the Solar Physics Observatory and fellow of St. John's College. His experience with the 72-inch Victoria reflector made him an obvious choice as chief assistant to Dr. Knox Shaw when the Radeliffe Observatory moved from Oxford to Pretoria to complete for the southern sky the work of the Victoria telescope in the northern hemisphere. A series of unhappy delays has so far prevented the Radcliffe Observer and his staff from getting the 74-inch mirror with which the programme was to have been carried out, and Dr. Redman returns with some of his plans unfulfilled. But he has from his days at Victoria, Cambridge and Pretoria a good volume of first-class work to his credit, mainly in the spheres of photometry and spectrophotometry. With close attention to the instrumental conditions essential to success, he has made very careful studies of the contours of Fraunhofer lines both at the centre of the sun's disk and on the limb, of chromospheric lines as seen at a total eclipse and of the absorption lines at different stages of eclipse of one component of a binary star. He has been a member of four eclipse expeditions, in 1927, 1932, 1936 and 1940. In 1940 he was favoured with fine weather, and secured some valuable spectrographic observations : the high temperature, $30,000^{\circ}$, which he found for the chromosphere and the strength of the weak Fraunhofer lines at the extreme limb of the sun are results which are not yet fully understood. His direct photometry includes work on the Andromeda and other nebulæ and on the use of the Fabry method in stellar photometry. He is at present co-operating with Dr. Stoy of the Cape Observatory on standard stellar magnitudes for the southern sky. 